\title{
Cloning, expression in Pichia pastoris, and characterization of a thermostable GH5 mannan endo- I,4- $\beta$-mannosidase from Aspergillus niger BKO I
}

\author{
Do Bien-Cuong', Dang Thi-Thu' ${ }^{1}$, Jean-Guy Berrin ${ }^{2}$, Dietmar Haltrich ${ }^{3}$, \\ To Kim-Anh' ${ }^{1}$, Jean-Claude Sigoillot ${ }^{2,4}$ and Montarop Yamabhai*5
}

\begin{abstract}
Address: ${ }^{1}$ Institute of Biological and Food Technology, Hanoi University of Technology, Hanoi, Vietnam, ${ }^{2}$ INRA, UMR1163 de Biotechnologie des Champignons Filamenteux, ESIL, 163 avenue de Luminy, CP 925, 13288 Marseille Cedex 09, France, ${ }^{3}$ BOKU - University of Natural Resources and Applied Life Sciences, Vienna, Austria, ${ }^{4}$ Université de Provence, UMR1163 de Biotechnologie des Champignons Filamenteux, ESIL, 163 Avenue de Luminy, CP 925, 13288 Marseille Cedex 09, France and 5School of Biotechnology, Institute of Agricultural Technology, Suranaree University of Technology, 111 University Avenue, Nakhon Ratchasima, 30000, Thailand
\end{abstract}

Email: Do Bien-Cuong - dobiencuong-ibft@mail.hut.edu.vn; Dang Thi-Thu - dangthudhbk@yahoo.com; Jean-Guy Berrin - jeanguy.berrin@univmed.fr; Dietmar Haltrich - dietmar.haltrich@boku.ac.at; To Kim-Anh - tokimanh@mail.hut.edu.vn; Jean-

Claude Sigoillot - jean-claude.sigoillot@esil.univmed.fr; Montarop Yamabhai* - montarop@sut.ac.th

* Corresponding author

Published: 13 November 2009

Microbial Cell Factories 2009, 8:59
Received: 18 July 2009

Accepted: 13 November 2009

This article is available from: http://www.microbialcellfactories.com/content/8/1/59

(C) 2009 Bien-Cuong et al; licensee BioMed Central Ltd.

This is an Open Access article distributed under the terms of the Creative Commons Attribution License (http://creativecommons.org/licenses/by/2.0), which permits unrestricted use, distribution, and reproduction in any medium, provided the original work is properly cited.

\begin{abstract}
Background: Mannans are key components of lignocellulose present in the hemicellulosic fraction of plant primary cell walls. Mannan endo-I,4- $\beta$-mannosidases (I,4- $\beta$-D-mannanases) catalyze the random hydrolysis of $\beta$-I,4-mannosidic linkages in the main chain of $\beta$-mannans. Biodegradation of $\beta$-mannans by the action of thermostable mannan endo-I,4- $\beta$-mannosidase offers significant technical advantages in biotechnological industrial applications, i.e. delignification of kraft pulps or the pretreatment of lignocellulosic biomass rich in mannan for the production of second generation biofuels, as well as for applications in oil and gas well stimulation, extraction of vegetable oils and coffee beans, and the production of value-added products such as prebiotic mannooligosaccharides (MOS).

Results: A gene encoding mannan endo- I,4- $\beta$-mannosidase or I,4- $\beta$-D-mannan mannanohydrolase (E.C. 3.2.I.78), commonly termed $\beta$-mannanase, from Aspergillus niger BKOI, which belongs to glycosyl hydrolase family 5 (GH5), was cloned and successfully expressed heterologously (up to 243 $\mu \mathrm{g}$ of active recombinant protein per $\mathrm{mL}$ ) in Pichia pastoris. The enzyme was secreted by P. pastoris and could be collected from the culture supernatant. The purified enzyme appeared glycosylated as a single band on SDS-PAGE with a molecular mass of approximately $53 \mathrm{kDa}$. The recombinant $\beta$-mannanase is highly thermostable with a half-life time of approximately $56 \mathrm{~h}$ at $70^{\circ} \mathrm{C}$ and $\mathrm{pH} 4.0$. The optimal temperature (10-min assay) and $\mathrm{pH}$ value for activity are $80^{\circ} \mathrm{C}$ and $\mathrm{pH} 4.5$, respectively. The enzyme is not only active towards structurally different mannans but also exhibits low activity towards birchwood xylan. Apparent $\mathrm{K}_{\mathrm{m}}$ values of the enzyme for konjac glucomannan (low viscosity), locust bean gum galactomannan, carob galactomannan (low viscosity), and I,4- $\beta$-Dmannan (from carob) are $0.6 \mathrm{mg} \mathrm{mL}^{-1}, 2.0 \mathrm{mg} \mathrm{mL}^{-1}, 2.2 \mathrm{mg} \mathrm{mL}^{-1}$ and $1.5 \mathrm{mg} \mathrm{mL}^{-1}$, respectively, while the $k_{\text {cat }}$ values for these substrates are $215 \mathrm{~s}^{-1}, 330 \mathrm{~s}^{-1}, 292 \mathrm{~s}^{-1}$ and $148 \mathrm{~s}^{-1}$, respectively. Judged from the specificity constants $k_{c a t} / K_{m}$, glucomannan is the preferred substrate of the $A$. niger $\beta$ -
\end{abstract}


mannanase. Analysis by thin layer chromatography showed that the main product from enzymatic hydrolysis of locust bean gum is mannobiose, with only low amounts of mannotriose and higher manno-oligosaccharides formed.

Conclusion: This study is the first report on the cloning and expression of a thermostable mannan endo-I,4- $\beta$-mannosidase from $A$. niger in Pichia pastoris. The efficient expression and ease of purification will significantly decrease the production costs of this enzyme. Taking advantage of its acidic $\mathrm{pH}$ optimum and high thermostability, this recombinant $\beta$-mannanase will be valuable in various biotechnological applications.

\section{Background}

$\beta$-1,4-Mannans are among the main hemicellulose components that are widespread in wood, tubers, plant seeds and beans [1,2]. The structural diversity of mannans allows for a wide range of physico-chemical properties. When some of the mannose residues are replaced by glucose residues, as in the glucomannans, or substituted with galactose residues, as in galactomannans, the water-solubility of the polymers increases, whereas pure mannans are insoluble [3]. In lignocellulosic biomass these polysaccharides associate with lignin and cellulose, protecting the fibers against degradation by cellulases and microbial attack [1]. Lignocellulose is seen as a promising feedstock for the production of second-generation biofuels. For this application, the carbohydrate components in lignocellulose should be completely converted into ethanol, and enzymatic degradation of these polysaccharides is an attractive approach.

Thermostability of the employed enzymes is essential during the pre-treatment step in the conversion of lignocellulosics biomass to fermentable sugars, since steam is used to make the biomass more accessible to enzymatic attack. Thus, enzymatic hydrolysis can take place directly after the heating step, without the need to significantly pre-cool the system; hence shortening processing time, saving energy, lowering of risk of contamination, and improving saccharification and fermentation yields. Thus, overall economy of the process can be increased [4,5]. Furthermore, the saccharification step can be combined with the fermentation (simultaneous saccharification and fermentation, SSF) in order to reduce the inhibition of hydrolysis by glucose or other monosaccharides. Since fermentations for bioethanol will be run under aseptic conditions to reduce costs, increased fermentation temperatures will reduce the risk of microbial contamination. Therefore, increased thermostability for the saccharification enzymes is preferable.

Biodegradation of $\beta$-mannans by the action of thermostable mannan endo-1,4- $\beta$-mannosidase or 1,4- $\beta$-D-mannan mannanohydrolase (E.C. 3.2.1.78), commonly known as $\beta$-mannanase, offers significant technical advantages for delignification of kraft pulps [6] and for various industrial applications, such as oil and gas well stimulation $[2,7]$, extraction of vegetable oils or coffee beans $[6,8]$, bioconversions of non-utilized lignocellulosic substrates rich in mannan into added-value products (e.g., chemicals, feed, prebiotic manno-oligosaccharides) $[2,9]$, or for the production of second generation biofuels [8-10].

Mannan endo-1,4- $\beta$-mannosidases, which are stable and efficiently functional at high temperatures, are found in several thermophilic bacteria, eubacteria $[7,10-12]$, actinomycetes [13] and fungi $[4,8,14,15]$. Some genes encoding thermostable mannan endo-1,4- $\beta$-mannosidase of bacterial origin have been cloned, sequenced and expressed in E. coli $[11,16]$. Most of these enzymes belong to glycosyl hydrolase family 26 (GH26) according to the Carbohydrate Active Enzymes database, http:// www.cazy.org[17]. Mannan endo-1,4- $\beta$-mannosidases that belong to glycosyl hydrolase family 5 (GH5) are found in bacteria [18], fungi [19] as well as higher plants [20]. Up to now, only one thermostable GH5 mannan endo-1,4- $\beta$-mannosidase gene from the fungus Bispora sp. MEY-1 was cloned and expressed in Pichia pastoris [15].

Our preliminary studies showed that the recently isolated strain Aspergillus niger BK01 (formerly termed Aspergillus sp. BK) produced thermostable mannan endo- $1,4-\beta$-mannosidase activity [21]. However, the high viscosity of the induction media containing guar gum and coffee pulp waste caused difficulties for fermentation and thus limited the scale-up for the production of this enzyme on an industrial scale. Molecular biology technology provides an opportunity to express and subsequently purify A. niger mannan endo-1,4- $\beta$-mannosidase in host strains capable of producing large amounts of secreted protein by industrial-scale fermentations based on well-established protocols [22].

This report describes cDNA cloning and successful heterologous expression of a novel thermostable GH5 mannan endo-1,4- $\beta$-mannosidase gene from $A$. niger BK01 in $P$. pastoris. In addition, several biochemical properties of the recombinant enzyme are reported. 


\section{Results \\ Cloning and sequence analysis of the mannan endo-I,4- $\beta$ - mannosidase gene from A. niger BKOI}

A 1035-nucleotide sequence encoding the mature mannan endo-1,4- $\beta$-mannosidase from Aspergillus niger BK01 (GenBank accession number FJ268574) was amplified by RT-PCR as described in the Methods section. The deduced amino acid sequence showed 70 to $93 \%$ similarity to different Aspergillus $\beta$-mannanases (Fig. 1). The enzyme belongs to glycosyl hydrolase family 5 [17]. It shows several characteristics common to all of the mannan endo$1,4-\beta$-mannosidases in this family, for example a catalytic center containing catalytically/structurally important Asn, Glu, and His residues. Two catalytic glutamates (Glu196, Glu303) and five out of the six active site residues (Arg81, His129 and His268, Asn195, Tyr270, Trp333) are con- served, corresponding to the known structures of other GH5 mannan endo-1,4- $\beta$-mannosidases [13,23].

\section{Heterologous expression of the A. niger mannan endo- $\mathbf{I , 4 - \beta} \beta$-mannosidase in $\mathbf{P}$. pastoris}

The nucleotide sequence encoding the mature form of $A$. niger BK01 mannan endo-1,4- $\beta$-mannosidase was cloned into the pPICZ $\alpha$ A vector. The recombinant enzyme was constructed such that the native signal peptide of the $A$. niger $\beta$-mannanase was replaced by that of the Saccharomyces cerevisiae $\alpha$-factor signal peptide. The resulting plasmid was then transformed into P. pastoris by electroporation. After transformation and primary screening on plates containing Zeocin in varying concentrations, antibiotic-resistant transformants were evaluated for their ability to secrete active mannanase on plates containing Azo-carob galactomannan (BMGY-Azo). Among 40 transformants

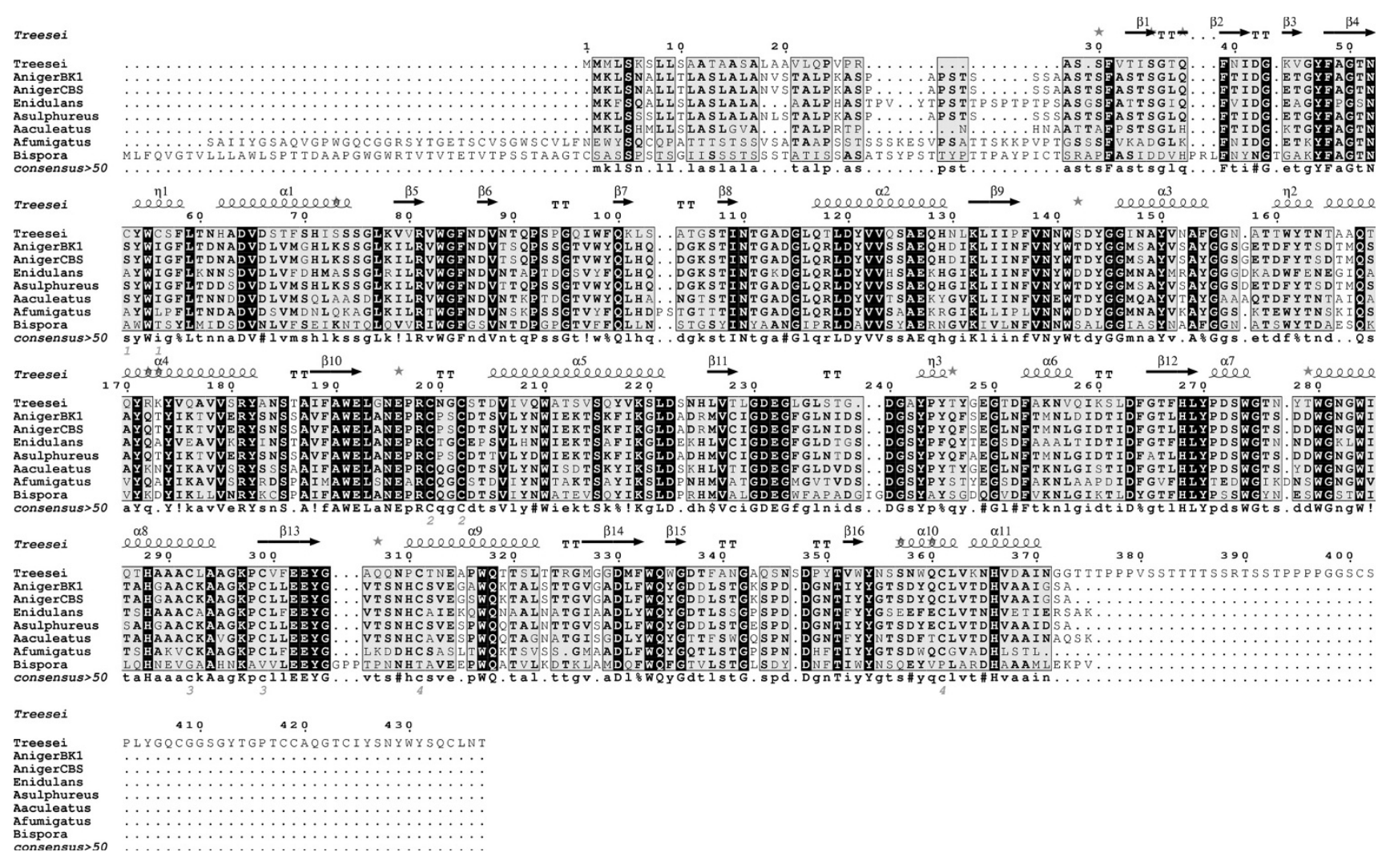

\section{Figure I}

Amino acid sequence alignment of mannan endo- $\beta$ - I,4-mannosidase from Aspergillus niger BKOI and related fungi. Multiple sequence alignment was done by CLUSTAL W [40] followed by ESPript [4I] to display the secondary structures using Trichoderma reesei mannanase as a template (pdb no. I qnr). $\alpha$-Helices are displayed as squiggles; $\beta$-strands are rendered as arrows, strict $\beta$-turns as TT letters. Percent similarities of mannan endo-I,4- $\beta$-mannosidase from $A$. niger BKOI (GenBank accession no. FJ268574) to other enzymes are $51 \%$ for T. reesei (GenBank accession no. $\underline{\text { L253IO }}$ ), $99 \%$ for A. niger CBS 5I3.88 (Genbank accession no. XP 001390707), 93\% for A. sulphureus (GenBank accession no. DQ328335), 7I\% for A. aculeatus (GenBank accession no. L35487), 66\% for Emericella nidulans (GenBank accession no. DQ490487), 56\% for Aspergillus fumigatus (GenBank accession no. EU925594), and 43\% for Bispora sp. MEY-I (GenBank accession no. EU919724). 
displaying mannan endo-1,4- $\beta$-mannosidase activity on the agar plates, the clone yielding the largest clearing halo was selected for cultivation in liquid culture.

Under appropriate conditions (2\% methanol, initial cell density $6 \times 10^{7}$ cells $\mathrm{mL}^{-1}$, $\mathrm{pH} 6.0$ ) the highest extracellular mannan endo-1,4- $\beta$-mannosidase activity (669 $\mathrm{U} \mathrm{mL}^{-1}$ ) could be obtained after a 96 -hour incubation at $28^{\circ} \mathrm{C}$. No $\beta$-mannanase activity was detected in the culture medium of the control strain under identical culture conditions. SDS-PAGE analysis of the crude supernatants at the induction period from 24 to $96 \mathrm{~h}$ showed a single band of 53 $\mathrm{kDa}$ (Fig. 2A), corresponding to mannan endo-1,4- $\beta$ mannosidase activity in the zymogram analysis (Fig. 2B). The ratio of secreted to intracellular $\beta$-mannanase activity was estimated to be approximately 3:1 (data not shown).

\section{Purification of recombinant mannan endo- $I, 4-\beta$ mannosidase}

The recombinant enzyme could be purified to apparent homogeneity both by immobilized metal affinity (IMAC) chromatography and size exclusion chromatography on Superdex. However, we found that the yield of the purified enzyme after chromatography on the Superdex column was higher (data not shown). This might be due to instability of the recombinant $\beta$-mannanase in the buffer at $\mathrm{pH} 7.5$, which was used for equilibration and elution during IMAC chromatography. After purification on the Superdex column as described in the Methods section, the specific activity of the purified enzyme (2570 U mg-1)

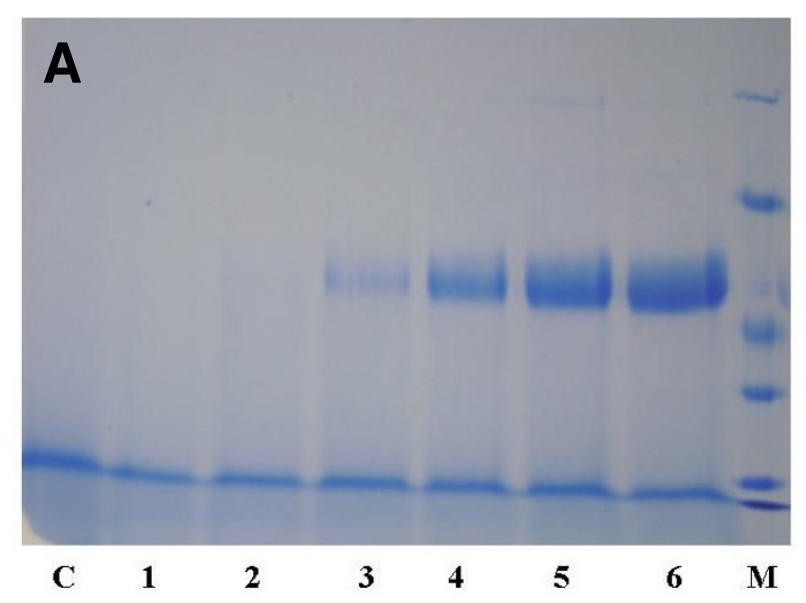

showed a 5.5-fold increase compared with the crude culture supernatant of $P$. pastoris (Table 1).

Purified recombinant mannan endo-1,4- $\beta$-mannosidase displayed one single band with an apparent molecular mass of $53 \mathrm{kDa}$ on SDS-PAGE. When the enzyme was treated with Endoglycosidase $\mathrm{H}$, the apparent molecular mass of the deglycosylated enzyme was approximately 47 $\mathrm{kDa}$ (Fig. 3), indicating that mannan endo-1,4- $\beta$-mannosidase is a glycoprotein, which is glycosylated to a degree of approximately $12 \%$. IEF revealed one single isoform of pI 4.7 (not shown), in good agreement with the theoretical pI deduced from the amino-acid sequence.

\section{Characterization of recombinant mannan endo- I,4- $\beta$ - mannosidase}

Effect of temperature and $\mathrm{pH}$ on enzyme activity and stability The effect of temperature and $\mathrm{pH}$ were investigated on recombinant $A$. niger BK01 mannan endo-1,4- $\beta$-mannosidase using locust bean gum mannan as substrate. The enzyme displayed over 50\% activity in the temperature range of 50 to $90^{\circ} \mathrm{C}$ with an optimal temperature at $80^{\circ} \mathrm{C}$ for the 10-min assay at pH 6.0 (Fig. 4). The enzyme was stable up to $70^{\circ} \mathrm{C}$. Practically all of its activity (>98\%) was retained after a 4 -h incubation at $70^{\circ} \mathrm{C}$, and the half-life time at this temperature was $56 \mathrm{~h}$. At $80^{\circ} \mathrm{C}$ the half-life time of activity of $A$. niger $\beta$-mannanase was only $15 \mathrm{~min}$, and at $90^{\circ} \mathrm{C}$ about $90 \%$ of its activity was lost within 2.5 min of incubation (Fig. 5). The optimal pH for mannan endo- $1,4-\beta$-mannosidase (at $80^{\circ} \mathrm{C}$ ) was $\mathrm{pH} 4.5$, and more than $80 \%$ of its maximal activity was retained within a

\section{Figure 2}

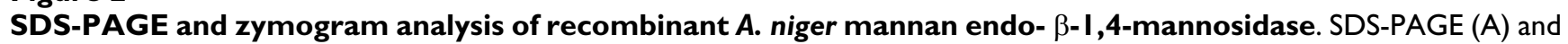
zymogram (B) of secreted proteins from recombinant Pichia pastoris expressing the $A$. niger $\beta$-mannanase are shown. Lane $M$, molecular mass standard protein; Lane I-6, culture supernatant after induction for 6, 24, 36, 48, 72 and 96 h, respectively; Lane $\mathrm{C}$, control of $P$. pastoris $X 33$ harbouring the empty PPICZ $\alpha A$ vector after induction for $96 \mathrm{~h}$. Twelve $\mu \mathrm{L}$ of culture supernatant was loaded onto each lanes. 
Table I: One-step purification of recombinant $\beta$-mannanase from $A$. niger

\begin{tabular}{llllll}
\hline Step & Total protein $\mathbf{( m g )}$ & Total activity $(\mathbf{U})$ & Specific activity $\left(\mathbf{U} \mathbf{~ m g}^{-1}\right)$ & $\begin{array}{l}\text { Degree of purification (fold) } \\
\text { Yield } \\
(\%)\end{array}$ \\
\hline $\begin{array}{llllll}\text { Culture supernatant } \\
\text { Superdex } 75\end{array}$ & 42.6 & 20870 & 471 & 1.0 & 100 \\
& 3.9 & 10200 & 2570 & 5.5 & 50.7 \\
\hline
\end{tabular}

rather broad $\mathrm{pH}$ range (from $\mathrm{pH}$ 4.0-5.5) (Fig. 6). The enzyme was stable in a narrow range around its optimal $\mathrm{pH}$ value (pH 4.5-5.0) (Fig. 7)

Effect of metal ions and chemical reagents on mannan endo-I,4- $\beta$ mannosidase activity

The relative activities (in parenthesis) of the enzyme after incubation with various reagents revealed that mannan endo-1,4- $\beta$-mannosidase from $A$. niger BK01 was strongly inhibited by sodium dodecyl sulfate, SDS (20.5\%), and $\mathrm{Mn}^{2+}(34.9 \%)$, and slightly inhibited by phenylmethylsulphonylfluoride, PMSF (75.2\%), $\mathrm{Na}^{+}(72.6 \%)$, $\mathrm{Zn}^{2+}(86.6 \%), \mathrm{Mg}^{2+}(87.4 \%), \mathrm{K}^{+}(89.7 \%), \mathrm{Ca}^{2+}(90.5 \%)$ and $\mathrm{Fe}^{2+}(95.8 \%)$. On the contrary, EDTA $(235.6 \%)$ and $\mathrm{Cu}^{2+}(110 \%)$ could activate this enzyme.

\section{Substrate specificity and kinetics parameters}

The relative activity of the purified enzyme on various substrates was determined as described in Methods. Mannan endo-1, 4- $\beta$-mannosidase from $A$. niger exhibited high activity on locust bean gum (100\%), but showed considerably less activity on guar gum (17.9\% relative activity) and birchwood xylan (9.1\%). Its activity is negligible on starch, carboxymethylcellulose and $\alpha$-cellulose $(<0.1 \%)$.

The Michaelis-Menten constants were determined for mannan-containing polysaccharides from various sources (Table 2). These substrates have different structures because of the different ratios of monomers found in the backbone and side chain substituents. For example, glucomannan from konjac has a glucose to mannose ratio of 0.66 to 1 ; galactomannan from locust bean gum (Sigma) has a mannose to galactose ratio of 4:1, while those from carob (Megazyme) and guar gum have a mannose to galactose ratio of $3.76: 1$ and 1.6:1, respectively. The $K_{m}$ and $\mathrm{k}_{\mathrm{cat}}$ values were $0.6 \mathrm{mg} \mathrm{mL}^{-1}$ and $215 \mathrm{~s}^{-1}$ for low viscosity glucomannan from konjac, $2.0 \mathrm{mg} \mathrm{mL}^{-1}$ and $330 \mathrm{~s}^{-1}$ for locust bean gum galactomannan, $2.2 \mathrm{mg} \mathrm{mL}^{-1}$ and $292 \mathrm{~s}^{-1}$ for low viscosity galactomannan from carob, $1.5 \mathrm{mg} \mathrm{mL}^{-1}$ and $148 \mathrm{~s}^{-1}$ for $\beta$-mannan from carob, and $7.7 \mathrm{mg} \mathrm{mL}^{-1}$ and $352 \mathrm{~s}^{-1}$ for guar galactomannan.

\section{Product analysis}

Analysis of oligosaccharide products obtained during enzymatic hydrolysis of locust bean gum using thin layer

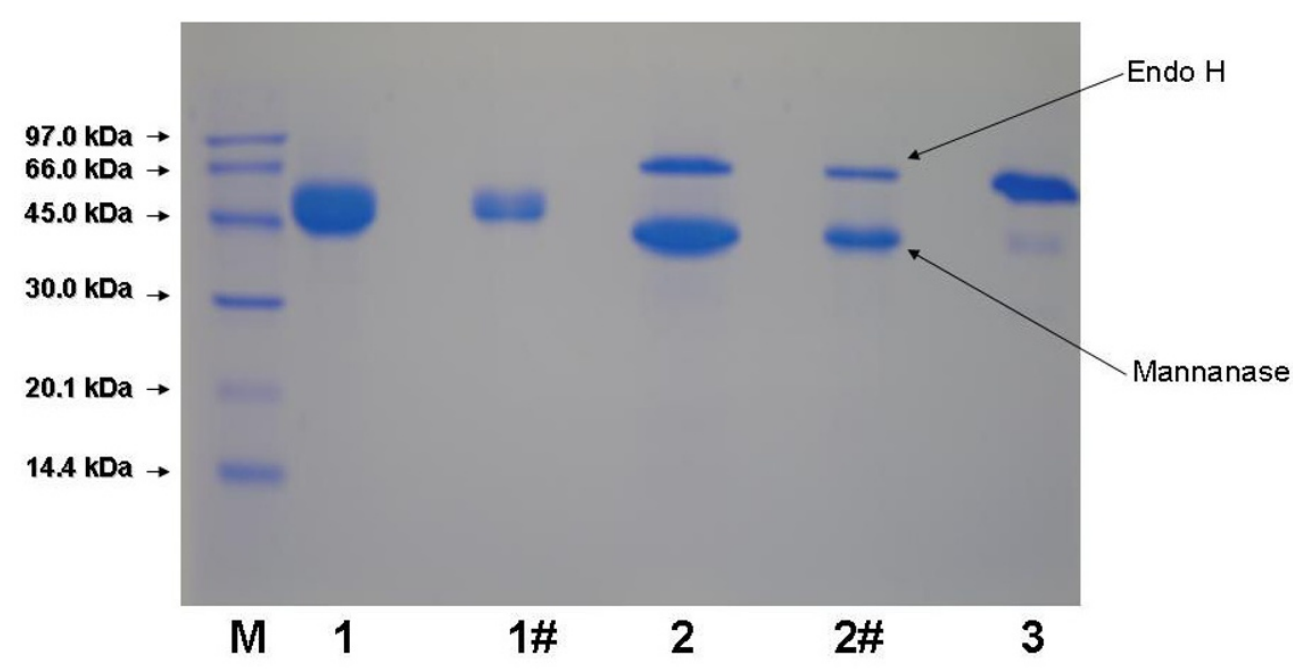

Figure 3

Deglycosylation of recombinant $\boldsymbol{A}$. niger mannan endo- $\beta$ - I,4-mannosidase. SDS-PAGE analysis of the recombinant mannan endo-I,4- $\beta$-mannosidase after deglycosylation with endoglycosidase $\mathrm{H}$. Lane $\mathrm{M}$ : molecular mass standard protein; Lane I: purified $\beta$-mannanase; Lane I\#: diluted purified $\beta$-mannanase; Lane 2: deglycosylated $\beta$-mannanase after endoH treatment; Lane 2\#: diluted deglycosylated $\beta$-mannanase; Lane 3: endoglycosidase $\mathrm{H}$. 


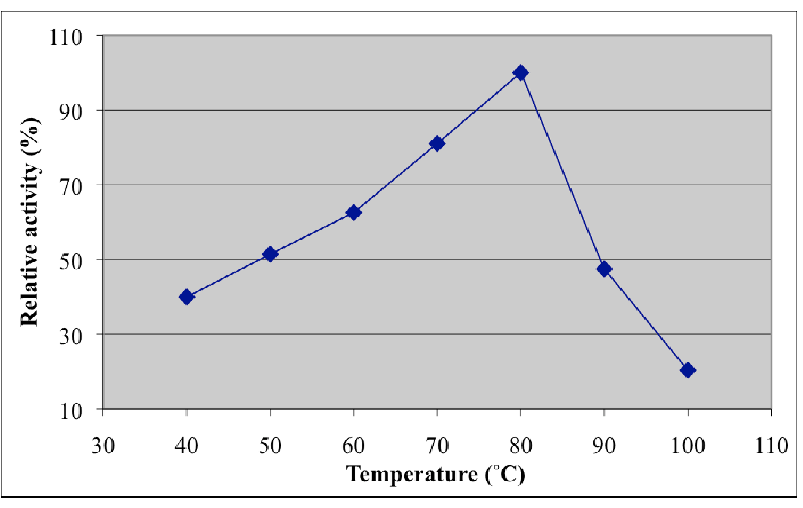

Figure 4

Effect of temperature on mannan endo- $\beta$ - I,4-mannosidase activity. The optimal temperature was determined using $0.5 \%$ locust bean gum in $0.1 \mathrm{M}$ citrate-phosphate buffer, $\mathrm{pH} 4.0$, in the 10-min assay.

chromatography revealed that the recombinant mannan endo-1,4- $\beta$-mannosidase from $A$. niger yields mannobiose as its main product, and a small amount of different oligosaccharides (Fig. 8). No trace of mannose could be detected in these hydrolysis experiments.

\section{Discussion}

The mannan endo-1,4- $\beta$-mannosidase of A.niger BK01 and the hypothetical protein (An05 g01320) of A.niger CBS513.18 are highly similar with 99\% amino acid sequence identity, and 98\% DNA sequence similarity. Their amino acid sequences also match the N-terminal sequence of native $A$. niger mannan endo-1,4- $\beta$-mannosidase that was reported in 1998 [24]. We have thoroughly

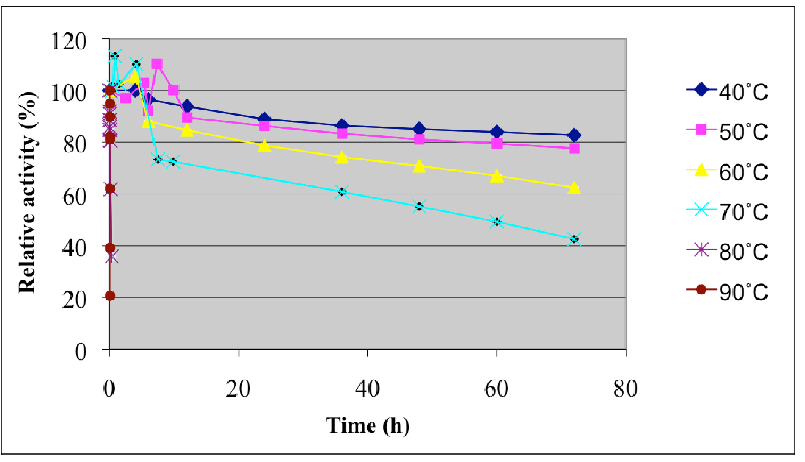

\section{Figure 5}

Effect of temperature on stability of $A$. niger BKOI $\beta$ mannanase. The temperature stability is shown as relative residual activity after incubation without substrate at different temperatures and at $\mathrm{pH}$ 4.0.

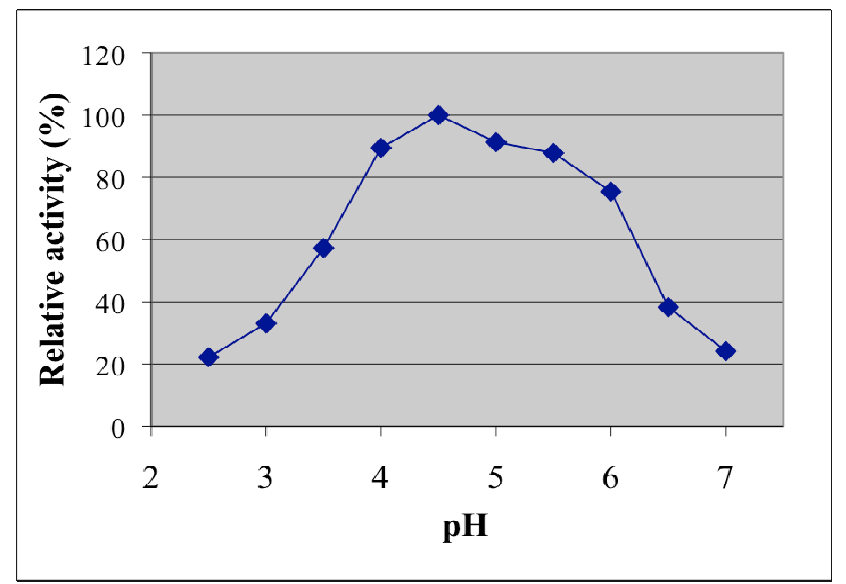

\section{Figure 6}

Effect of pH on mannan endo- $\beta$ - I,4-mannosidase activity. The optimal $\mathrm{pH}$ was determined at $80^{\circ} \mathrm{C}$ using $0.5 \%$ LBG in $0.1 \mathrm{M}$ citrate-phosphate buffer over a $\mathrm{PH}$ range of 2.5-7.0.

searched the databases and could not find any report on cloning, expression, and characterization of an A. niger mannan endo- $1,4-\beta$-mannosidase. Thus, our work is the first report on cloning, expression and characterization of this enzyme. In addition, this work also helps verify the function of the hypothetical protein (An05 g01320) of A.niger CBS513.18 that has been reported to have strong similarity to mannanase $(\operatorname{man} 1)$ from $A$. aculeatus. $\beta$ Mannanases from A. niger BK01 [21], A. niger CBS513.18 and $A$. niger published by Ademark et al [24] appear to be

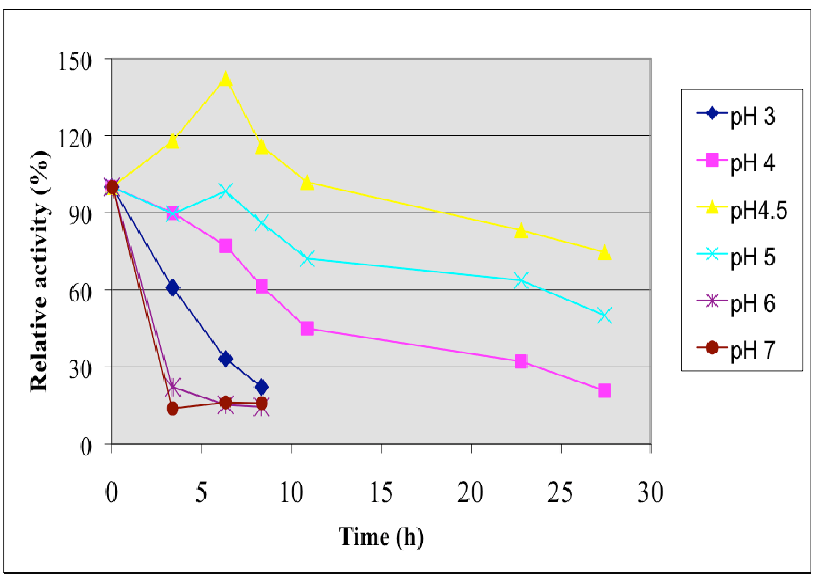

\section{Figure 7}

Effect of pH on stability of $A$. niger BKOI $\beta$-mannanase. The $\mathrm{pH}$ stability was reported as relative residual activity after the enzyme was incubated in $0.1 \mathrm{M}$ citrate-phosphate buffer at various $\mathrm{pHs}$ without substrate for different periods of time at $50^{\circ} \mathrm{C}$. 
Table 2: Kinetic parameters for the purified mannan endo- I,4- $\beta$-mannosidase ${ }^{\mathrm{a}}$ at $70^{\circ} \mathrm{C}$

\begin{tabular}{|c|c|c|c|c|}
\hline Substrate & $\mathbf{V}_{\max }(\mathbf{U} \mathrm{mg}-\mathrm{I})$ & $K_{m}(m g ~ m L-I)$ & $\mathbf{k}_{\text {cat }}(\mathrm{s}-\mathrm{I})$ & kcat $/ K m\left(\mathrm{mg}^{-1} \mathrm{~s}^{-1} \mathrm{~mL}\right)$ \\
\hline Glucomannan & $243 \pm 15$ & $0.6 \pm 0.3$ & 215 & 358 \\
\hline Locust bean gum & $373 \pm 19$ & $2.0 \pm 0.4$ & 330 & 165 \\
\hline Galactomannan & $330 \pm 9$ & $2.2 \pm 0.2$ & 292 & 133 \\
\hline Mannan & $167 \pm 5$ & $1.5 \pm 0.2$ & 148 & 98.4 \\
\hline Guar gum & $398 \pm 48$ & $7.7 \pm 1.8$ & 352 & 45.7 \\
\hline
\end{tabular}

a Enzymatic reactions were carried out for $5 \mathrm{~min}$ at $70^{\circ} \mathrm{C}$ in $0.07 \mathrm{M}$ citrate phosphate buffer ( $\left.\mathrm{pH} 4.5\right)$.

closely related and have similar properties, which are superior than those from A. niger NRRL 337 [25]. Mannan endo-1,4- $\beta$-mannosidases from other Aspergillus species e.g., those from A. aculeatus, A. fumigatus or A. sulphureus, have previously been cloned and expressed in various hosts [26-31]. A. niger $\beta$-mannanase has unique properties that are different from other Aspergillus mannanases. Amino acid sequence of $A$. niger BK01 mannan endo-1,4$\beta$-mannosidases including putative signal peptide can be found in additional file 1 .

Mannan endo-1,4- $\beta$-mannosidases or $\beta$-mannanases have been classified into two family of glycoside hydrolases, i.e., family 5 and 26, based on their sequence similarity http://www.cazy.org. The A. niger mannan endo-1,4- $\beta$ mannosidase belongs to glycoside hydrolase family 5 (GH5). Analysis of the primary sequence of fungal mannan endo-1,4- $\beta$-mannosidases belonging to this family

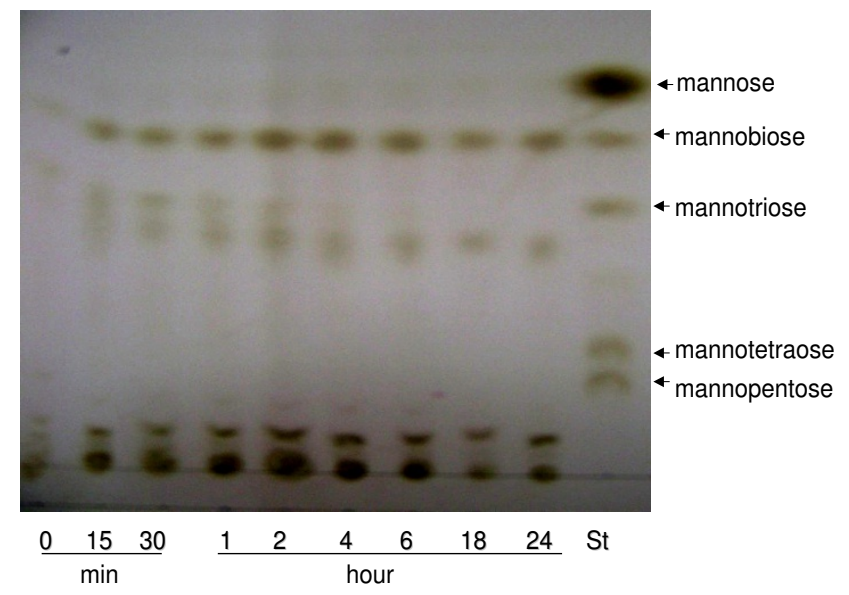

Figure 8

Thin layer chromatography analysis. Products from locust bean gum hydrolysis by recombinant $A$. niger mannanase at various time points were separated on silica plates. Incubation times (hour or minute) are indicated. Lane St indicates authentic standards, i.e. a mixture of mannose to mannopentaose. Ten $\mu \mathrm{L}$ of hydrolysate was spotted onto each lane. revealed amino acid sequence similarities ranging from 43 to $93 \%$. Some fungal $\beta$-mannanases have been shown to contain a cellulose-binding domain (CBD) at either the C-terminus or N-terminus of the enzyme. For example, CBD of $T$. reesei $\beta$-mannanase is located at its C-terminus (amino acid position 373-410) preceded by a serine-, threonine-, and proline-rich region [29], whereas CBD of A. fumigatus $\beta$-mannanase is located at its N-terminus (amino acid position 9-44) as shown in Fig. 1. A role of this domain in the hydrolysis of mannan/cellulose complex substrates has been suggested [32]. However, $\beta$-mannanases from different fungi including $A$. niger do not contain a CBD. The protruding N-terminus of Bispora $s p$. as shown in the sequence alignment in Fig. 1 is not similar to a CBD, and its role in catalysis still remains to be explored.

The mature $A$. niger mannan endo-1,4- $\beta$-mannosidase gene without its signal peptide was expressed in $P$. pastoris $\mathrm{X} 33$ with the C-terminus of the recombinant enzyme fused to the $6 \mathrm{xHis}$ tag for affinity purification by immobilized metal affinity chromatography (IMAC). The native signal peptide was replaced with that of the Saccharomyces cerevisiae $\alpha$-factor, allowing secretion of the active enzyme into the extracellular medium with an expression yield of approximately $243 \mathrm{mg} \mathrm{L}^{-1}$. Since cultivation experiments were done in shake flasks, one can expect that growth of $P$. pastoris in a fermentor under controlled and optimised conditions will result in considerably higher protein yields [33]. In comparison, the expression level of Trichoderma reesei mannan endo-1,4- $\beta$-mannosidase in $S$. cerevisiae was roughly $150 \mathrm{mg} \mathrm{L}^{-1}$ [29] and that of Bispora sp. MEY-1 [15] and B. subtilis mannan endo-1,4- $\beta$-mannosidase in $P$. pastoris GS115 [34] was $1800 \mathrm{mg} \mathrm{L}^{-1}$ and $150 \mathrm{mg} \mathrm{L}^{-1}$, respectively. Moreover, the enzyme activity during fermentation reached $670 \mathrm{U} \mathrm{mL}^{-1}$, which is significantly higher than those reported for most mannan endo-1,4- $\beta$-mannosidases [26,34].

Amino acid sequence analysis by the NetNGlyc 1.0 sever program indicated two putative $\mathrm{N}$-glycosylation sites in the amino acid sequence of mannan endo-1,4- $\beta$-mannosidase i.e., ${ }^{195} \mathrm{NSS}^{197}$, and ${ }^{252} \mathrm{NFT}^{254}$ (according to num- 
bering in Fig. 1). The deglycosylation analysis, showed in Fig. 3, confirms the prediction that the enzyme is glycosylated. Purified mannan endo-1,4- $\beta$-mannosidase treated with Endoglycosidase $H$ was calculated to be 43 kDa by SDS-PAGE. This result indicated that the A. niger mannan endo-1,4- $\beta$-mannosidase expressed in $P$. pastoris was properly glycosylated, as the enzyme was as active as the native enzyme.

Recombinant A. niger BK01 mannan endo-1,4- $\beta$-mannosidase efficiently hydrolysed galactomannans, glucomannans and $\beta-1,4-$ mannans from different sources. Although determination of kinetic parameters enabled us to demonstrate that $A$. niger GH5 mannan endo- $1,4-\beta-$ mannosidase was highly active towards structurally different mannans, this enzyme displayed highest specificity towards unsubstituted carob glucomannan with a $\mathrm{K}_{\mathrm{m}}$ and $\mathrm{k}_{\text {cat }}$ of $0.6 \mathrm{mg} \cdot \mathrm{mL}^{-1}$ and $215 \mathrm{~s}^{-1}$, respectively. Based on these kinetic parameters, mannanase activity of this enzyme appears not to be hampered by the presence of side chains, i.e. galactosyl residues. The enzyme can hydrolyse galactomannans as well as glucomannans and unsubstituted $\beta-1,4$-mannan. The action of the enzyme on these substrates as well as on Azo-carob galactomannan, a standard substrate for the assessment of mannan endo-1,4- $\beta$-mannosidase activity, indicates its function as a true endo- $\beta-1,4-$ mannanase. This activity was confirmed by TLC analysis of reaction products obtained through hydrolysis of locust bean gum, which gave mannobiose as major product and no detectable mannose, indicating that the enzyme has no $\beta$-mannosidase activity. In addition to mannan, A. niger mannanase was capable of degrading birchwood xylan ( $9.1 \%$ relative activity). Its lacks of activity for cellulose is valuable for applications in bleaching pulp and paper [1].

In general, the properties of the recombinant mannan endo-1,4- $\beta$-mannosidase from $A$. niger are very similar to those of the enzyme from its natural source with only some minor differences. The recombinant $A$. niger mannan endo-1,4- $\beta$-mannosidase furthermore shows properties typical of thermostable enzymes, which is in accordance with the wild-type enzyme. The optimal temperature of its activity is $80^{\circ} \mathrm{C}$, similar to that of the native enzyme [21]. Optimal temperatures of different fungal $\beta$ mannanases have previously been reported; that of the $\beta$ mannanase from Trichoderma reesei C-30 was found at $75^{\circ} \mathrm{C}[35]$, whereas $\beta$-mannanase produced from $A$. niger and $A$. flavus showed their optimum at 65 and $60^{\circ} \mathrm{C}$, respectively [14]. Two forms of mannan endo-1,4- $\beta$-mannosidase from the thermotolerant fungus $A$. fumigatus IMI 385708 showed highest activity at $60^{\circ} \mathrm{C}(\mathrm{pH} 4.5)$ [6]. These rather high optima appear to be a common but valuable characteristic of fungal $\beta$-mannanases. At such high temperatures (above $60-65^{\circ} \mathrm{C}$ ), enzymatic digestion may not only increase the rate of hydrolysis but also reduce microbial contamination of the material being processed [36].

Both native and recombinant $A$. niger mannan endo-1,4$\beta$-mannosidase appear to be among the most thermostable fungal $\beta$-mannanases reported to date. The recombinant $A$. niger mannan endo-1,4- $\beta$-mannosidase retained $>98 \%$ activity after $4 \mathrm{~h}$ at $70^{\circ} \mathrm{C}$, while mannan endo-1,4$\beta$-mannosidase from Talaromyces emersonii and Aspergillus niger NRRL 337 retained 53\% and 20\% activity after $1 \mathrm{~h}$ at $65^{\circ} \mathrm{C}$, respectively [36]. The half-life of thermostable acidic mannan endo-1,4- $\beta$-mannosidase from Sclerotium (Athelia) rolfsii at $70^{\circ} \mathrm{C}$ and $\mathrm{pH} 4.5$ was $1.5 \mathrm{~h}$ [37], while that of recombinant $A$. niger mannan endo-1,4- $\beta$-mannosidase at $70^{\circ} \mathrm{C}$ was $56 \mathrm{~h}$. Bispora sp. MEY-1 mannan endo-1,4- $\beta$-mannosidase, which was expressed in $P$. pastoris, only retained more than $50 \%$ of its initial activity after an incubation at $70^{\circ} \mathrm{C}$ for $20 \mathrm{~min}$ [15].

The strong increase of the enzyme activity in the present of EDTA $(1 \mathrm{mM})$ suggests that metal ions are not present in the active site and are not required for activity. At the same concentration, the effect of EDTA on A. sulphureus $\beta$ mannanase activity was only moderate [26]. EDTA might protect the enzyme against the detrimental effect of metal ions present in the enzyme preparation, which inhibit the A. niger $\beta$-mannanase to a certain extent while not affecting the $A$. sulphureus enzyme significantly. For example, $\mathrm{Mn}^{2+}$ strongly inhibited the A. niger $\beta$-mannanase but did not effect the latter enzyme. Other ions including $\mathrm{Na}^{+}$, $\mathrm{Zn}^{2+}, \mathrm{Mg}^{2+}, \mathrm{Ca}^{2+}, \mathrm{Fe}^{2+}$ exerted an adverse effect on the activity of $A$. niger $\beta$-mannanase but did not affect or slightly increased the $A$. sulphureus $\beta$-mannanase activity [26]. The $\beta$-mannanase activity inhibition in the presence of PMSF ( $1 \mathrm{mM}$ ) was $24.8 \%$, suggesting the role of a serine in the catalytic action of $A$. niger mannan endo-1,4- $\beta$ mannosidase.

\section{Conclusion}

To date, this study is the first report on production of a thermostable GH5 mannan endo-1,4- $\beta$-mannosidase from A. niger using a $P$. pastoris expression system. This kind of thermostable enzyme can gain a great deal of interest for industrial applications in large scale due to an increasing demand towards renewable resource utilization in the near future.

\section{Methods}

\section{Strains, plasmids, enzymes, reagents, and growth media}

Aspergillus niger strain BK01, isolated from an orange in Vietnam, was identified by the Center of Biotechnology, Vietnam National University, Hanoi, and is preserved in our laboratory. Escherichia coli strain TOP 10 (Invitrogen) was used as a host for molecular cloning of DNA in pPIC- 
$\mathrm{Z} \alpha \mathrm{A}$ (Invitrogen) and propagation of recombinant expression vectors. Pichia pastoris X33 (Invitrogen) was used for heterologous protein expression. All media and protocols for Pichia are described in the Pichia expression manual (Invitrogen). Manno-oligosaccharides were from Megazyme (Bray, Ireland).

\section{Total RNA isolation, cDNA synthesis and cloning of the mannan endo-I,4- $\beta$-mannosidase gene}

A. niger $\mathrm{BK} 01$ was grown at $37^{\circ} \mathrm{C}$ for $48 \mathrm{~h}$ in a plate containing $10 \mathrm{~mL}$ liquid modified Czapek medium including locust bean gum as a sole carbon source $\left(5 \mathrm{~g} \mathrm{~L}^{-1}\right)$. The mycelium was then transferred to a plate containing 10 $\mathrm{mL} \beta$-mannanase induction medium based on modified coffee pulp waste $\left(21.6 \mathrm{~g} \mathrm{~L}^{-1}\right)$ and guar gum $\left(10 \mathrm{~g} \mathrm{~L}^{-1}\right)$ [21]. After a 72-h growth period, the mycelium was harvested. Total RNA was isolated by extracting $50 \mathrm{mg}$ of mycelium using the RNeasy Plant Mini Kit (Qiagen, Valencia, CA). cDNA was synthesized from RNA using One Step RT-PCR Kit (Qiagen) according to the manufacturer's instructions. The primers used were CF (5'-ATG AAG CTT TCC AAC GCC CTC CTC-3') and CR (5'-TTA AGC ACT ACC AAT AGC AGC AAC ATG ATC-3'), which were designed according to the amino acid sequence of the putative mannan endo-1,4- $\beta$-mannosidase from $A$. niger CBS 513.88 (Genbank accession no. XP 001390707) The thermocycling parameters were: $50^{\circ} \mathrm{C}$ for $35 \mathrm{~min}, 95^{\circ} \mathrm{C}$ for $15 \mathrm{~min}$ and 30 cycles of $94^{\circ} \mathrm{C}-30 \mathrm{~s}, 54^{\circ} \mathrm{C}-45 \mathrm{~s}$ and $72^{\circ} \mathrm{C}-90 \mathrm{~s}$, followed by $10 \mathrm{~min}$ extension at $72^{\circ} \mathrm{C}$.

To subclone the mannan endo-1,4- $\beta$-mannosidase cDNA into the expression vector, the $\beta$-mannanase-encoding sequence was amplified from the previously isolated cDNA with the primers PNf (5'-CTG TGC GAA TTC TCC TTC GCC AGC ACC TCC G-3'), including an EcoRI site, and PRv (5'-CTG TGC TCT AGA GCA CTA CCA ATA GCA GCA ACA TGA TCC - 3 '), including a XbaI site, using a mixture of $P f u$ DNA polymerase (3 U/reaction) and Taq DNA polymerase ( $3 \mathrm{U} /$ reaction). The thermocycling parameters were $95^{\circ} \mathrm{C}$ for $2 \mathrm{~min}$, and 30 cycles of $95^{\circ} \mathrm{C}$ for $45 \mathrm{~s}, 59^{\circ} \mathrm{C}$ - $45 \mathrm{~s}$ and $72^{\circ} \mathrm{C}-3 \mathrm{~min}$. The DNA insert was cloned into $E c o R I$ and $X b a I$ sites of the PPICZ $\alpha A$ vector, downstream of the $\alpha$-factor signal peptide sequence. Proper construction was confirmed by restriction digestion and automated DNA sequencing (Macrogen Inc., Korea). The DNA sequence encoding mature mannan endo-1,4- $\beta$-mannosidase was deposited in the GenBank database under accession no. FJ268574.

\section{Expression of the mannan endo-I,4- $\beta$-mannosidase gene in Pichia pastoris}

The selected expression plasmid was linearized with SacI (New England BioLabs, USA), and then transformed into $P$. pastoris strain X33 by electroporation [22]. Transformants were first screened from YPDS (1\% yeast extract, $2 \%$ peptone, $2 \%$ dextrose, $1 \mathrm{M}$ sorbitol, $2 \%$ agar) plates containing Zeocin ${ }^{\mathrm{TM}}$ at a final concentration of $100 \mu \mathrm{g} \mathrm{mL}^{-1}$, then on YPDZ plates (1\% yeast extract, $2 \%$ peptone, $2 \%$ dextrose and $2 \%$ agar containing Zeocin at final concentrations of 150,300 , and $500 \mu \mathrm{g} \mathrm{mL}^{-1}$ ) in order to screen for higher copy numbers of the targeted gene. Recombinant strains producing mannan endo-1,4- $\beta$-mannosidase were further confirmed by BMGY-Azo plates $(1 \%$ yeast extract, $2 \%$ peptone, $100 \mathrm{mM}$ potassium phosphate pH 6.0, 1.34\% YNB, $4 \times 10^{-5} \%$ biotin, $0.5 \%$ methanol, $2 \%$ agar and $0.3 \%$ Azo-carob galactomannan). Mut ${ }^{+}$phenotype of $P$. pastoris recombinants was analysed by genomic PCR with 5'AOX and 3'AOX primers. The culture medium from the $P$. pastoris transformant that had the highest $\beta$-mannanase activity was used for the subsequent analysis of the recombinant protein. A control was transformed with an empty pPICZ $\alpha$ A plasmid.

\section{Purification of recombinant mannan endo- I,4- $\beta$ - mannosidase}

All purification steps were performed at $4{ }^{\circ} \mathrm{C}$ unless stated otherwise. The crude culture supernatant was obtained by centrifugation of the culture broth at $4000 \mathrm{rpm}$ for $5 \mathrm{~min}$ at $4{ }^{\circ} \mathrm{C}$. The crude supernatant was concentrated 30 -fold by ultrafiltration through a $10-\mathrm{kDa}$ cut-off membrane (Sartorius Stedim Biotech, Germany). The final purification was done by size exclusion chromatography on a Superdex 75 HR 10/30 column (Amersham Pharmacia Biotech, Sweden) equilibrated with $50 \mathrm{mM}$ potassium phosphate buffer, $\mathrm{pH}$ 6.0, and the protein was eluted at a flow rate of $1 \mathrm{~mL} \mathrm{~min}{ }^{-1}$. Active fractions were combined and used in further experiments as the purified $\beta$-mannanase.

\section{Polyacrylamide gel electrophoresis and zymograms}

Sodium dodecyl sulfate polyacrylamide gel electrophoresis (SDS-PAGE) was performed in a $12.5 \%\left(\mathrm{w} \mathrm{v}^{-1}\right)$ polyacrylamide gel by the method of Laemmli (1970). Proteins were stained with Coomassie brilliant blue G-250.

Zymograms were obtained by co-polymerizing $0.2 \%\left(\mathrm{w} \mathrm{v}^{-}\right.$ 1) locust bean gum with $12.5 \%\left(\mathrm{w} \mathrm{v} \mathrm{v}^{-1}\right)$ polyacrylamide gel as previously reported [38]. After electrophoresis, the gel was soaked in $2.5 \%$ cold Triton X100 with gentle shaking to remove SDS and re-fold the proteins in the gel. The gel was then washed four times at $4^{\circ} \mathrm{C}$ in $50 \mathrm{mM}$ potassium phosphate buffer pH 6.0 for $30 \mathrm{~min}$. After incubation for $45 \mathrm{~min}$ at $50^{\circ} \mathrm{C}$, the gels were stained with Congo red solution $\left(0.1 \%, \mathrm{w} \mathrm{v}^{-1}\right)$, and destained with $1 \mathrm{M} \mathrm{NaCl}$. The activity bands were observed as clear yellow halos.

Deglycosylation of recombinant $\beta$-mannanase Purified mannan endo-1,4- $\beta$-mannosidase was deglycosylated by denaturing the protein at $100^{\circ} \mathrm{C}$ for $10 \mathrm{~min}$ prior to the addition of endoglycosidase $H_{f}$ (Endo $H_{f}$ New England 
Biolabs) at $37^{\circ} \mathrm{C}$ for $1 \mathrm{~h}$ according to the manufacturer's instructions.

\section{$\beta$-Mannanase assay and protein quantification}

Mannan endo-1,4- $\beta$-mannosidase activity was determined using the 3,5-dinitrosalicylic acid (DNS) method [39]. The reaction was started by mixing $0.1 \mathrm{~mL}$ of appropriately diluted enzyme sample with $0.9 \mathrm{~mL}$ of $5 \mathrm{mg} \mathrm{mL}^{-1}$ locust bean gum in $0.1 \mathrm{M}$ citrate-phosphate buffer, $\mathrm{pH}$ 4.0. After 10 -min incubation at $50^{\circ} \mathrm{C}$, the reaction was stopped by the addition of $5 \mathrm{~mL}$ DNS reagent. One unit of mannan endo-1,4- $\beta$-mannosidase activity is defined as the amount of enzyme releasing $1 \mu$ mole of mannose equivalents per minute. All experiments were done in triplicate, and average values are reported. Protein concentration was determined with bovine serum albumin as standard, using the Micro-BCA Protein Assay Reagent (Biorad, USA).

\section{Effect of temperature, $\mathrm{pH}$ and various reagents on enzyme activity}

The optimal temperature for mannan endo-1,4- $\beta$-mannosidase activity (10-min assay) was determined by the standard activity assay as described above at various temperatures ranging from 40 to $100^{\circ} \mathrm{C}$. To estimate thermal stability, the enzyme was pre-incubated in $0.1 \mathrm{M}$ citratephosphate buffer ( $\mathrm{pH} 4.0)$ at various temperatures (60$90^{\circ} \mathrm{C}$ ) for different periods of time without substrate and then assayed for residual activity at $50^{\circ} \mathrm{C}$ using the standard activity assay. The effect of $\mathrm{pH}$ on $\beta$-mannanase activity was determined at $80^{\circ} \mathrm{C}$ over a pH range of 2.5-7.0 by using $0.1 \mathrm{M}$ citrate-phosphate buffer. To estimate $\mathrm{pH}$ stability, the enzyme was diluted/pre-incubated in the same buffer at different $\mathrm{pH}$-values for different periods of time at $50^{\circ} \mathrm{C}$ without substrate, and then assayed for residual activity at $\mathrm{pH} 4.0$. The effect of ions on mannan endo-1,4$\beta$-mannosidase activity was examined by incubating the enzyme with $1 \mathrm{mM}$ of various metal ions in $0.1 \mathrm{M}$ sodium citrate buffer ( $\mathrm{pH} 4.0)$ at $50^{\circ} \mathrm{C}$ for $30 \mathrm{~min}$.

\section{Substrate specificity and kinetic parameters}

The substrate specificity of purified recombinant mannan endo-1,4- $\beta$-mannosidase was evaluated with the following substrates at $5 \mathrm{mg} \mathrm{mL}^{-1}$ in $0.1 \mathrm{M}$ citrate-phosphate buffer, pH 4.0: locust bean gum (Sigma), guar gum (Sigma), birchwood xylan (Roth), soluble starch (SigmaAldrich), $\alpha$-cellulose and carboxyl methyl cellulose (Fluka). Activity was measured by the dinitrosalicylic acid (DNS) method as described above. For the kinetic experiments, $0.1 \mathrm{M}$ citrate-phosphate buffer ( $\mathrm{pH} 4.5$ ) containing 0.1 to $10 \mathrm{mg} \mathrm{mL}^{-1}$ of various mannan substrates (i.e., locust bean gum (Sigma), guar gum (Sigma), carob galactomannan (low viscosity) (Megazyme), konjac glucomannan (low viscosity) (Megazyme), and carob 1,4- $\beta$-Dmannan (Megazyme), was incubated with the purified mannan endo-1,4- $\beta$-mannosidase at $70^{\circ} \mathrm{C}$ for $5 \mathrm{~min}$. Kinetic parameters $\left(\mathrm{K}_{\mathrm{m}}\right.$ and $\left.\mathrm{v}_{\max }\right)$ were calculated from the experimentally obtained data and non-linear regression analysis using the "GraFit" software (Erithacus Software Ltd.).

\section{Thin layer chromatography}

Locust bean gum was prepared at a concentration of $1 \%$ $\left(\mathrm{w} \mathrm{v}^{-1}\right)$ in $50 \mathrm{mM}$ sodium citrate buffer, $\mathrm{pH}$ 4.5. After addition of the purified enzyme (7.5 U for 2-mL reactions), the solution was incubated at $40^{\circ} \mathrm{C}$. Aliquots were removed at various time, and heated to $100^{\circ} \mathrm{C}$ for $10 \mathrm{~min}$. Hydrolysis products were separated on silica plates $60 \mathrm{~F}$ 254 (Merck, Darmstadt, Germany) using a solvent system consisting of 1-propanol-nitromethane-water $\left(7: 1: 2, \mathrm{v} \mathrm{v}^{-}\right.$ $1)$. The products were detected by spraying with $5 \%$ sulphuric acid in ethanol followed by heating at $110^{\circ} \mathrm{C}$ for about 5 min. Manno-oligosaccharides (mannose, mannobiose, mannotriose, mannotetraose and mannopentose, Megazyme) were used as standards.

\section{Competing interests}

The authors declare that they have no competing interests.

\section{Authors' contributions}

DBC performed most parts of the experiments and prepared the first draft of the manuscript. DTT and TKA directed the study. JBG checked all data, designed the frame of this publication and revised the draft. JCS codesigned the frame of this publication. DTT, TKA, JGB and JCS also co-supervised enzyme characterization. DH initiated expression in Pichia pastoris and edited the manuscript. MY conceived of the study, supervised molecular biology work, participated in sequence alignment and edited the manuscript. All authors read and approved the final manuscript.

\section{Additional material}

\section{Additional file 1}

Complete amino acid sequence of A. niger BK01 mannan endo-1,4- $\beta$ mannosidase including native signal peptide. Amino acid sequence in FASTA format of the entire mannan endo-1,4- $\beta$-mannosidase from Aspergillus niger BK01, including putative signal peptide. Click here for file

[http://www.biomedcentral.com/content/supplementary/14752859-8-59-S1.pdf]

\section{Acknowledgements}

This work was supported by the National Research Council of Thailand (NRCT), Faculty and Student Exchange Program between Thailand and Neighbour Countries 2007, T2008-219 project (Hanoi University of Technology), Regional Center of Excellence Project (PER) (Agency for French Speaking Universities) and the ASEAN University Network Program 
(AUNP). The authors would like to thank Prof. Truong Nam Hai and Dr. Do Thi Huyen (Vietnam Academy of Science and Technology) for valuable advices on the expression studies; MSc. V.T.K.Thoa for technical assistance; and MY lab members for their friendship and technical advices.

\section{References}

I. Dhawan S, Kaur J: Microbial mannanases: an overview of production and applications. Crit Rev Biotechnol 2007, 27(4): 197-216.

2. Gübitz G, Sachslehner A, Haltrich D: Microbial mannanases: substrates, production and application. In Glycosyl Hydrolases for Biomass Conversion Volume 769. Washington, DC: ACS Symposium Series, American Chemical Society; 2001:239-262.

3. Schroder R, Atkinson RG, Redgwell RJ: Re-interpreting the role of endo- $\beta$-mannanases as mannan endotransglycosylase/hydrolases in the plant cell wall. Ann Bot (Lond) 2009, 104(2):197-204.

4. Turner P, Mamo G, Karlsson EN: Potential and utilization of thermophiles and thermostable enzymes in biorefining. Microb Cell Fact 2007, 6:9.

5. Viikari L, Alapuranen M, Puranen T, Vehmaanpera J, Siika-Aho M: Thermostable enzymes in lignocellulose hydrolysis. Adv Biochem Eng Biotechnol 2007, I08: I 2 I- 145.

6. Puchart V, Vrsanská M, Svoboda P, Pohl J, Ogel ZB, Biely P: Purification and characterization of two forms of endo- $\beta-$ I,4-mannanase from a thermotolerant fungus, Aspergillus fumigatus IMI 385708 (formerly Thermomyces lanuginosus IMI I 58749). Biochimica et Biophysica Acta (BBA) - General Subjects 2004, 1674(3):239-250.

7. Duffaud GD, McCutchen CM, Leduc P, Parker KN, Kelly RM: Purification and characterization of extremely thermostable beta-mannanase, beta-mannosidase, and alpha-galactosidase from the hyperthermophilic eubacterium Thermotoga neapolitana 5068. Appl Environ Microbiol 1997, 63(I): 169-177.

8. Sachslehner A, Foidl G, Foidl N, Gubitz G, Haltrich D: Hydrolysis of isolated coffee mannan and coffee extract by mannanases of Sclerotium rolfsii. J Biotechnol 2000, 80(2): I27-I34.

9. Sanchez C: Lignocellulosic residues: biodegradation and bioconversion by fungi. Biotechnol Adv 2009, 27(2): I85-194.

10. Jiang Z, Wei Y, Li D, Li L, Chai P, Kusakabe I: High-level production, purification and characterization of a thermostable $\beta$ mannanase from the newly isolated Bacillus subtilis WY34. Carbohydrate Polymers 2006, 66 (I):88-96.

II. Luthi E, Jasmat NB, Grayling RA, Love DR, Bergquist PL: Cloning, sequence analysis, and expression in Escherichia coli of a gene coding for a beta-mannanase from the extremely thermophilic bacterium "Caldocellum saccharolyticum". Appl Environ Microbiol I99I, 57(3):694-700.

12. Talbot G, Sygusch J: Purification and characterization of thermostable beta-mannanase and alpha-galactosidase from Bacillus stearothermophilus. Appl Environ Microbiol 1990, 56(I I):3505-35I0.

13. Hilge M, Gloor SM, Rypniewski W, Sauer O, Heightman TD, Zimmermann W, Winterhalter K, Piontek K: High-resolution native and complex structures of thermostable beta-mannanase from Thermomonospora fusca - substrate specificity in glycosyl hydrolase family 5. Structure 1998, 6(II): 1433-I444.

14. Kote NV, Patil AG, Mulimani VH: Optimization of the production of thermostable endo-beta-I,4 mannanases from a newly isolated Aspergillus niger gr and Aspergillus flavus gr. Appl Biochem Biotechnol 2009, I52(2):21 3-223.

15. Luo H, Wang Y, Wang H, Yang J, Yang Y, Huang H, Yang P, Bai Y, Shi $P$, Fan $Y$, et al.: A novel highly acidic beta-mannanase from the acidophilic fungus Bispora sp. MEY-I: gene cloning and overexpression in Pichia pastoris. Appl Microbiol Biotechnol 2009, 82(3):453-46I.

16. Politz O, Krah M, Thomsen KK, Borriss R: A highly thermostable endo-(I,4)-beta-mannanase from the marine bacterium Rhodothermus marinus. Appl Microbiol Biotechnol 2000, 53(6):715-72I.

17. Cantarel BL, Coutinho PM, Rancurel C, Bernard T, Lombard V, Henrissat B: The Carbohydrate-Active EnZymes database (CAZy): an expert resource for Glycogenomics. Nucleic Acids Res 2009:D233-238.

18. Ethier N, Talbot G, Sygusch J: Gene cloning, DNA sequencing, and expression of thermostable beta-mannanase from Bacil- lus stearothermophilus. Appl Environ Microbiol 1998, 64(II):4428-4432.

19. Aparicio R, Fischer $H$, Scott DJ, Verschueren $K H$, Kulminskaya AA, Eneiskaya EV, Neustroev KN, Craievich AF, Golubev AM, Polikarpov I: Structural insights into the beta-mannosidase from $T$. reesei obtained by synchrotron small-angle $X$-ray solution scattering enhanced by X-ray crystallography. Biochemistry 2002, 4I(30):9370-9375.

20. Bourgault R, Oakley AJ, Bewley JD, Wilce MC: Three-dimensional structure of $(I, 4)$-beta-D-mannan mannanohydrolase from tomato fruit. Protein Sci 2005, 14(5): | 233-124|

21. Thu DT, Cuong DB: Purification and characterization of an endo- $\beta$-I,4-mannanase from Aspergillus sp. BK. Journal of Science and Technology (Vietnamese) 2004, 42(5):38-43.

22. Cregg JM, ed: Pichia Protocols. 2nd edition. Totowa, New Jersey: Humana Press; 2007

23. Sabini E, Schubert H, Murshudov G, Wilson KS, Siika-Aho M, Penttila M: The three-dimensional structure of a Trichoderma reese beta-mannanase from glycoside hydrolase family $\mathbf{5}$. Acta Crystallogr D Biol Crystallogr 2000, 56(Pt I):3-I3.

24. Ademark P, Varga A, Medve J, Harjunpaa V, Torbjorn D, Tjerneld F, Stalbrand $H$ : Softwood hemicellulose-degrading enzymes from Aspergillus niger: Purification and properties of a $\beta$-mannanase. Journal of Biotechnology 1998, 63(3):199-210.

25. Araujo A, Ward P: Hemicellulases of Bacillus species: preliminary comparative studies on production and properties of mannanase and galactanases. Journal of Applied Bacteriology 1990, 68:253-261.

26. Chen $X, C a o$, Ding Y, Lu W, Li D: Cloning, functional expression and characterization of Aspergillus sulphureus beta-mannanase in Pichia pastoris. J Biotechnol 2007, I 28(3):452-46I.

27. Duruksu G, Ozturk B, Biely P, Bakir U, Ogel ZB: Cloning, expression and characterization of endo-beta- I,4-mannanase from Aspergillus fumigatus in Aspergillus sojae and Pichia pastoris. Biotechnol Prog 2009, 25(I):27I-276.

28. Setati ME, Ademark $\mathrm{P}$, van Zyl WH, Hahn-Hagerdal B, Stalbrand $\mathrm{H}$ : Expression of the Aspergillus aculeatus endo-beta-I,4-mannanase encoding gene (manl) in Saccharomyces cerevisiae and characterization of the recombinant enzyme. Protein Expr Purif 200I, 2I(I): 105-II4.

29. Stalbrand H, Saloheimo A, Vehmaanpera J, Henrissat B, Penttila M: Cloning and expression in Saccharomyces cerevisiae of a Trichoderma reesei beta-mannanase gene containing a cellulose binding domain. Appl Environ Microbiol 1995, 6 I (3): 1090-1097.

30. van Zyl PJ, Moodley V, Rose SH, Roth RL, van Zyl WH: Production of the Aspergillus aculeatus endo-I,4-beta-mannanase in $A$. niger. J Ind Microbiol Biotechnol 2009, 36(4):6 I I-6I7.

3I. Roth R, Moodley V, van Zyl P: Heterologous Expression and Optimized Production of an Aspergillus aculeatus Endo- I,4- $\beta$ mannanase in Yarrowia lipolytica. Molecular Biotechnology 2009, 43(2): II $12-120$.

32. Hagglund $P$, Eriksson T, Collen A, Nerinckx W, Claeyssens M, Stalbrand $\mathrm{H}$ : A cellulose-binding module of the Trichoderma reesei beta-mannanase Man5A increases the mannan-hydrolysis of complex substrates. J Biotechnol 2003, I 01 (I):37-48.

33. Gasser B, Saloheimo M, Rinas U, Dragosits M, Rodriguez-Carmona E, Baumann K, Giuliani M, Parrilli E, Branduardi P, Lang C, et al.: Protein folding and conformational stress in microbial cells producing recombinant proteins: a host comparative overview. Microb Cell Fact 2008, 7: II

34. He X, Liu N, Li W, Zhang Z, Zhang B, Ma Y: Inducible and constitutive expression of a novel thermostable alkaline $\beta$-mannanase from alkaliphilic Bacillus sp. NI6-5 in Pichia pastoris and characterization of the recombinant enzyme. Enzyme and Microbial Technology 2008, 43(1): I3-18.

35. Arisan-Atac I, Hodits R, Kristufek D, Kubicek CP: Purification, and characterization of a $\beta$-mannanase of Trichoderma reesei $C$ 30. Applied Microbiology and Biotechnology 1993, 39(I):58-62.

36. Araujo A, Ward OP: Extracellular mannanases and galactanases from selected fungi. Journal of Industrial Microbiology and Biotechnology 1990, 6(3): 17|-178.

37. Sachslehner A, Haltrich D: Purification and some properties of a thermostable acidic endo-beta-I,4-d-mannanase from Sclerotium (Athelia) rolfsii. FEMS Microbiology Letters 1999, I77(I):47-55. 
38. Yamabhai M, Emrat S, Sukasem S, Pesatcha P, Jaruseranee N, Buranabanyat B: Secretion of recombinant Bacillus hydrolytic enzymes using Escherichia coli expression systems. Journal of Biotechnology 2008, I 33(I):50-57.

39. Miller GL: Use of Dinitrosalicylic Acid Reagent for Determination of Reducing Sugar. Analytical Chemistry 1959, 3 I(3):426-428.

40. Larkin MA, Blackshields G, Brown NP, Chenna R, McGettigan PA, McWilliam H, Valentin F, Wallace IM, Wilm A, Lopez R, et al.: Clustal $\mathbf{W}$ and Clustal $\mathbf{X}$ version 2.0. Bioinformatics 2007, 23(2I):2947-2948.

41. Gouet P, Courcelle E, Stuart DI, Metoz F: ESPript: analysis of multiple sequence alignments in PostScript. Bioinformatics 1999 , I5(4):305-308.

Publish with Bio Med Central and every scientist can read your work free of charge

"BioMed Central will be the most significant development for disseminating the results of biomedical research in our lifetime. "

Sir Paul Nurse, Cancer Research UK

Your research papers will be:

- available free of charge to the entire biomedical community

- peer reviewed and published immediately upon acceptance

- cited in PubMed and archived on PubMed Central

- yours - you keep the copyright

Submit your manuscript here:

http://www.biomedcentral.com/info/publishing_adv.asp
BioMedcentral 